\title{
Primary medical care in former East Germany: the frosty winds of change
}

\author{
Ulrich Freudenstein, Günther Borgwardt
}

In October 1990 East and West Germany were reunited. Economic pressures, civil unrest, and the decision of the leadership of the USSR not to back further repression brought down the East German government. With Soviet consent reunification became possible.

This seemed the best of all worlds for stability in central Europe and freedom and prosperity for the East Germans. However, the path to such bliss turned out to be thornier than many imagined. East Germany had to accept that virtually all legal, administrative, and political structures would be changed according to the West German model. Unemployment, short time working, and migration to the western part (especially of skilled workers) are some of the problems plaguing the five new federal states.

Restructuring the health service might not have been considered the biggest problem under these circumstances, but the structure of eastern Germany's health service differed greatly from its western counterpart. Some of its elements were considered positive by trade unions and social democrats in western Germany and by most in the east. Changes would immediately affect large numbers of people. Time for preparation and negotiation was very short between the opening of borders in 1989 and the final decision to reunite the countries in 1990. The health service and its restructuring were more controversial than many other equally fundamental changes.

Sheffield S10 1NW

Ulrich Freudenstein, MRCGP, general practitioner

East German Association of General Practitioners, 0-1170 Berlin, Germany Günther Borgwardt, OMR, president

Correspondence to:

Dr Ulrich Freudenstein,

77 Slinn Street, Sheffield

S10 1NW.

BMF 1992;304:827-9

The East German health service before reunification

In the days of the German Democratic Republic the health service was centrally planned and funded. The administrative units were districts and areas. All medical staff were salaried, apart from a few hundred independent contractors left over from the immediate postwar era.

Primary care was provided from state owned health centres of different sizes (a few were owned by the churches but financed in the same way). Health centres had one to 50 generalist and specialist doctors and dentists working on or from their premises. Many smaller health centres were staffed and administered

The Germanies before reunification ${ }^{27}$

\begin{tabular}{|c|c|c|}
\hline Population (1988) & $\begin{array}{c}\text { East } \\
\text { Germany } \\
16675000\end{array}$ & $\begin{array}{c}\text { West } \\
\text { Germany } \\
61715000\end{array}$ \\
\hline Neonatal deaths/ 1000 live births (definitions of live births & & \\
\hline differ) & $8 \cdot 1$ & $7 \cdot 6$ \\
\hline $\begin{array}{l}\text { Working doctors/head of population (primary and } \\
\text { secondary care) }\end{array}$ & $1 / 400$ & $1 / 349$ \\
\hline Nurses $/ 10000$ population & 73 & 37 \\
\hline Average life expectancy (years): & & \\
\hline Men & $70(1988)$ & $72(1987)$ \\
\hline Women & 76 & 78 \\
\hline Unemployment & None (1987) & $8 \cdot 9 \%(1988)$ \\
\hline Method of financing health care & $\begin{array}{l}\text { Taxation and } \\
\text { single } \\
\text { national } \\
\text { insurance }\end{array}$ & $\begin{array}{l}\text { Insurance } \\
\text { contributions }\end{array}$ \\
\hline
\end{tabular}

from the larger ones. Larger centres were often but not always situated next to a district hospital. They housed laboratory, $x$ ray, and minor surgery facilities as well as services such as physiotherapy and counselling.

Workers were looked after by the occupational health service (about $14 \%$ of medical staff). ${ }^{1}$ Larger work places (industrial and other institutions) had occupational health centres on site, which provided surveillance, first aid, and primary care for workers and their families. Workers on smaller sites had access to a nurse and were visited by a doctor. The medical staff were mostly generalists with an occupational medicine training.

Paediatricians ran their own primary care service from the health centres. In rural areas they performed mostly immunisations and surveillance tasks.

Subspecialists (so called dispensaires) provided regular surveillance and treatment to groups such as pregnant women, diabetic patients, and other chronically sick whose care was deemed to require special skill. They also advised generalists on treatment. Only they could prescribe certain drugs. ${ }^{1-3} \mathrm{~A}$ centrally organised comprehensive community nursing service was in existence.

Problems were mostly due to scarce resources and inflexibility in local planning and budget distribution. The decision to emphasise the general practitioner's role as the family doctor (taken by the government in 1987) was one example of sensible policy that faltered due to lack of resources. The morale of health workers was low, and pay was low in comparison with West Germany.

The service was comprehensive and free at the point of need. There was no private medical care. Some institutions of the health service provided priority treatment to high ranking state and party officials.

Specialist and general practice training were well organised. Training for generalists took place in supernumerary posts in the larger health centres and lasted four years.

Vast amounts of data were collected as part of surveillance examinations. Disease registers (for those receiving care by dispensaires) and immunisation registers were also kept. ${ }^{1}$

In 1989, 2000 different drugs were licensed by the state. Three quarters were produced within East Germany and the remainder imported in about equal proportions from other Eastern bloc and Western countries. Shortages were apparently quite common, ${ }^{2}$ especially owing to variations in demand.

\section{The West German health service - a guiding light?}

In West Germany primary care doctors are independent contractors and paid on an item of service basis. There is no restriction on doctors to set up in practice, although recommendations exist. Both specialists and generalists carry out primary care. The chosen first doctor (generalist or general physician) vets onward referral to other specialists. Practitioners rarely work in groups, but some will share a building. For an independent contractor to employ another doctor on a long term basis is illegal. Hence there are few salaried doctors in primary care (other than 
trainees). General practitioners often receive little training (the minimum period of further training comprises six months after basic training). Specialists in general practice (so named to distinguish them from the other generalists) have to undergo four years of further training and often encounter difficulties in obtaining posts within specialist departments of their choice. $^{2}$

Payment is negotiated between the organisation of independent contractors and the insurance system, which is composed of about 1200 different organisations. Most of these function along "mutual society" lines - that is, they are not profit making. Opting out of such insurance is possible only for those above a certain income; insurance is compulsory for those below this level, and contributions are part of state benefit for those who receive any. Patients pay prescription charges, a percentage of the cost of some drugs, and a contribution towards the cost of dental treatment. Otherwise the service is free at the point of need. The service is better paid for and levels of investment are higher then in eastern Germany. Waiting for treatment, unless it is very specialised, is unusual. New technologies become quickly and widely available as soon as their use is accepted by the representatives of the insurance system.

Occupational health is clearly dissociated from primary care as a purely diagnostic process encompassing surveillance and medical examinations during employment. Other public health functions are carried out by medical staff employed by the state but again are completely separate from primary care and do not involve treatment. There is no equivalent to the East German dispensaire system.

The system of insurance has problems. Access to particular types of insurance is limited to certain types of employees. Sometimes workers in certain industries (such as coal) are in one particular insurance. Contributions as a percentage of salary vary from $8 \%$ to $15 \%$. This irrational and, in terms of administrative effort, wasteful structure has been widely criticised, ${ }^{24}$ but it has resisted reform.

Drugs are priced higher than in many other European countries. ${ }^{2}$ If combinations and different forms of one drug are counted separately, there are 40000 preparations on the market.

\section{Problems of change in eastern Germany}

The biggest problem facing the East German health service is its financing. The number of contributors to insurance has dropped and their income levels are lower. To avoid subsidy to the new federal states, wages and reimbursement levels for items of service (initially $45 \%$ of levels in western Germany) have been limited. Patients' payments towards drugs and dental treatment have been phased in. The German pharmaceutical industry agreed to contribute towards drug expenditure should this exceed a certain limit, but this will probably cover only about $12 \%$ of expenditure. ${ }^{45}$

The introduction of the West German insurance system created further difficulties. Setting up its administration and introducing the billing process was done by the organisations involved in running the West German health service "adopting" an area in the east. An insurance society, for example, would train staff and offer ongoing technical support. For the first year, payment to health centres took place on the basis of their expected level of activity. All are expected to produce ongoing returns for the billing systems to allow corrections. The amount of new paper work that was required proved to be a major stumbling block, with up to $30 \%$ incomplete returns. ${ }^{6}$

Changing a health service of employees into one of independent contractors (an aim incorporated into the reunification treaty) means that advantages of an integrated model of primary care are being exchanged for the isolation of the singlehanded independent contractor (the predominant type in western Germany). Health centres with employed doctors are allowed to continue until 1995, after which there are no plans. The pressure on doctors to become independent contractors and to do so soon is therefore enormous. About half of all primary care doctors had done so by October 1991, but many of the others are unlikely candidates for this step. Age over 50 and poor health are two factors making the application for a commercial loan to finance the change unsuccessful or unwise. Many of those doctors will still be around in 1995 . Their future is uncertain and their morale is low. Doctors who have become independent with a loan are under pressure to produce more items of service to pay for it.

Planning is difficult. Health centres lose doctors, their case load falls, and income with it. Some local authorities are wary of committing resources to the "employed sector." This leads to further discrepancies likely to deter patients. Previous assessments of the commercial viability of large health centres ${ }^{389}$ have become of little value with the rapid change in circumstances. Lower wages and reimbursement are leading to shortages of skilled staff-nurses, for example-in eastern Germany, and will also limit investment by independent contractors and health centres in equipment and buildings.

\section{Conclusions}

The level of service and the material conditions for patients should gradually improve within the eastern German health service as a consequence of reunification. Independent contractors may be more responsive to changes than the larger health centres. However, the social benefits of employee status will be lost for independent contractors. Older doctors face an uncertain future after 1995 .

The existing unease within the western part, with the deficiencies of its own structure of primary care, its financing, and its drug market, has been suppressed. The need to have the same system in both Germanies has at least temporarily stifled the debate. Not even the well organised training for general practice in East Germany survived reunification despite the fact that Germany will soon have to comply with European Community rules on the minimum further training of general practitioners.

The potential of a well resourced, integrated primary care system within health centres has been virtually ignored. If some of the larger health centres manage to survive and function until 1995 the case in their favour might be strengthened. The differential pay levels have created a drain of qualified staff such as nurses to the western states.

Reunification of two different health care delivery systems with one half on lower income and expenditure has thrown many of the problems of the western system into sharp focus. At the same time the speed of the changes has made it almost impossible to evaluate and incorporate those aspects of the East German health service that were positive.

We thank all those doctors and administrators in eastern Germany who provided help and information.

I Nowak M, Baumann M, Dehlinger E, Moehlmann H, Schmidt EH. Bewertende Beschrębung des Gesundheitswesens der DDR. Köln: Europäisches Zentrum für Angewandte Wirtschaftsforschung, 1990.

2 Arnold M, Schirmer B. Gesundheit für ein Deutschland. Köln: Deutscher Aerzteverlag, 1990

3 Schraeder W, Jacobs K. Zur Entwicklung der ambulanten medizinischen Versorgung in der Region Dresden. Berlin: Institut für Gesundheits- und Sozialforschung, 1991. 
4 Hofemann K. Systemwechsel im Gesundheitswesen. Soziale Sicherheit 1991;2: $37-42$.

Von Stackelberg J-M. Pharmaindustrie profitiert von Kompromiss. Soziale Sicherheit 1991;2:43-8.

6 Hess R. Polikliniken müssen mehr Eigeninitiative entwickeln. Humanitos $991 \cdot 7 \cdot 7$

7 Institut für Medizinische Statistik und Datenverarbeitung. Das Gesundheitswesen-Jahresgesundheitsbericht 1989 für das Gebiet der ehemaligen DDR. Berlin: Bundesministerium für Gesundheit, 1990.
8 Wibera Wirtschaftsberatung Aktiengesellschaft. Gutachten-Analyse der Leistungsfaktoren von Polikliniken und Ambulatonen in der Deutschen Demokratischen Republik-Phase 1. Düsseldorf, WWA, 1990.

9 Wibera Wirtschaftsberatung Aktiengesellschaft. Gutachten-Analyse der Leistungsfaktoren von Polikliniken und Ambulatorien auf dem Gebiet der ehemaligen Deutschen Demokratischen Republik - Phase 2. Düsseldorf: W/W/ 1991.

(Accepted 10 February 1992)

\title{
Counselling HIV positive haemophilic men who wish to have children
}

\author{
Eleanor Goldman, Riva Miller, Christine A Lee
}

All citizens of the United Kingdom, including people with HIV and AIDS, are awarded rights under international law which the United Kingdom government has agreed to uphold. Among these rights, which exist in international treaties, ' are the right to marry, the right to found a family, and the right to education.

Many haemophilic men were infected with HIV as a result of the administration of clotting factor concentrates before it was known that they were contaminated with HIV. A proportion of these were adolescent or young men who then, or later, had stable relationships and wished to have children.

\section{Present series}

It is the practice at the Royal Free Hospital's haemophilia centre to review severely affected haemophilic patients (factor VIII concentration $<20 \mathrm{U} / 1$ ) on a six monthly basis and mildly affected patients (factor VIII concentration $>20 \mathrm{U} / \mathrm{l}$ ) annually. Patients are asked to bring wives or sexual partners and family members to reviews so that the effects of haemophilia on the family can be addressed. A cohort of $111 \mathrm{HIV}$ positive haemophilic patients has been followed up since the first seroconversion in October 1979 to August $1991^{23}$ and, when possible, their partners and families have been seen at regular intervals.

Before HIV testing was available, between 1983 and 1984, information was provided about the likely modes of transmission of HIV and the inability at that time to diagnose those infected. Safer sexual practices, as described in "Haemofact Bulletin," were advocated. ${ }^{4}$ When HIV testing became available in early 1985 all haemophilic patients were invited to bring their sexual partners for counselling and HIV testing. Partners were interviewed separately and asked to answer confidential questions about their sexual practices.

By using confidential questionnaires to determine attitudes to childbearing 26 couples in stable relationships have been closely followed up, 24 since 1985 and two since 1987. Partners and children of HIV positive haemophilic patients have also been tested annually for HIV serology and CD4 lymphocyte count.

\section{Counselling}

The counselling technique used is based on that of the Milan associates. ${ }^{5}$ Questioning is used to engage the family and involve them in giving thought to their situation as well as revealing the views and attitudes of other family members. Exploring people's beliefs, wishes, and the extent of their knowledge of HIV enables them to make informed decisions. Sequential questions facilitate the discussion of difficult issues, while hypothetical, future oriented questions help the couple to understand some of the long term implica- tions of having a child. Examples of questions used to help people when they are considering whether to have a child are:

(1) What has made you decide that this is the right time to have a child?

(2) If you decided not to have children how would that affect you/your relationship?

(3) Which of you most wants to have a child?

(4) Is there anything about your family or your community which puts pressure on you to have children?

Questions are used not only to elicit information about the family but also to assist in imparting information by assessing the extent of the family's knowledge. In this way misconceptions can be corrected and gaps filled while members are actively engaged in thinking about the subject under consideration, rather than being flooded with information which they may not understand or be ready to accept. Questions can also be used to check the extent of their grasp of the information offered. For example, "If your sister/brother/girlfriend were to ask you to explain this what would you tell them?" and "How do you think that HIV is most often transmitted?"

If it was established that a couple did wish to have children they were asked to consider the following possible scenarios.

(1) The partner of an HIV positive haemophilic patient could remain HIV negative and have an uninfected child. The haemophilic partner might die earlier from progression of HIV disease than would normally be expected but the mother would have a child which she might otherwise not have had.

(2) The mother might become infected with HIV but the child could be uninfected and possibly become an orphan.

(3) Both mother and child could become infected with HIV, resulting in all three family members being infected.

(4) The woman could have artificial insemination with frozen semen from a screened donor so that she could experience having a child which she and her partner could share without the risk of HIV infection. If the child was a girl she would not be a carrier of haemophilia.

For those who felt that they wished to take one of these risks and proceed to have a child it was advised that they should practise safer sex-for example, using condoms at all times except at ovulation. The use of ovulation kits was recommended (and these have been provided at the Royal Free Hospital since 1988) to reduce the risk while attempting to achieve pregnancy. HIV testing of the mother was offered at three months' gestation if the couple had indicated that they would prefer to terminate the pregnancy in the event of her seroconversion. Provided the mother remained HIV negative and continued to use safe sexual practices
Correspondence to: Dr Goldman.

BMF 1992;304:829-30 